University for Business and Technology in Kosovo

UBT Knowledge Center

Oct 27th, 1:30 PM - 3:00 PM

\title{
Assessment of Lead Concentration in the Aerosol Sampling Using Different Analytical Techniques
}

\author{
Mirela Alushllari \\ University of Tirana, m.alushllari@gmail.com \\ Nikolla Civici \\ University of Tirana
}

Follow this and additional works at: https://knowledgecenter.ubt-uni.net/conference

Part of the Food Science Commons

\section{Recommended Citation}

Alushllari, Mirela and Civici, Nikolla, "Assessment of Lead Concentration in the Aerosol Sampling Using Different Analytical Techniques" (2018). UBT International Conference. 161.

https://knowledgecenter.ubt-uni.net/conference/2018/all-events/161

This Event is brought to you for free and open access by the Publication and Journals at UBT Knowledge Center. It has been accepted for inclusion in UBT International Conference by an authorized administrator of UBT Knowledge Center. For more information, please contact knowledge.center@ubt-uni.net. 


\title{
Assessment of Lead Concentration in the Aerosol Sampling Using Different Analytical Techniques
}

\author{
Mirela Alushllari $^{1^{*}}$, Nikolla Civici ${ }^{1}$ \\ ${ }^{1}$ Institute of Applied Nuclear Physics, University of Tirana, Tirana, Albania \\ m.alushllari@gmail.com
}

\begin{abstract}
The instrumental methods of analysis with destructive and nondestructive used to determine metals concentration in aerosol samples. The purpose of this study is to determine the lead concentration in aerosol samples using different analytical techniques. We have selected 8 aerosols samples, which are divided in two parts and only one in four parts. We have analyzed a total 18 filter aerosol samples. Aerosol samples are collected in Tirana and Elbasan cities and were analyzed for lead content by using Graphite Furnace Atomic Absorption Spectrometry, Flame Atomic Absorption Spectrometry and X-ray Fluorescence in the Institute of Applied Nuclear Physics, University of Tirana, Albania. From the results obtained show that the level of lead in the aerosol samples that are collected in Elbasan is higher than in samples are collected in Tirana. By the use of various techniques in the measurement of lead in aerosols it is noticed that the more information is obtained from the technique of X-ray while for the presence of lead in low concentrations, GFAAS technique has the highest accuracy and sensitivity
\end{abstract}

Keywords: lead concnetration, aerosols, instrumental methods.

\section{Introduction}

Air pollution represents one of the main problems of environmental pollution, especially in urban and industrial areas. Both natural and anthropogenic sources contribute to air pollution. The development of technology and production of primary products also, produces secondary production, solid, liquid and gaseous waste, whose presence is associated with significant environmental impacts (M. Alushllari et al. 2014). Quality of air is very important to ecosystems and human health. Atmospheric pollutants are responsible for both acute and chronic effects on human health (WHO, 2000). Trace metals, are the most common components in atmospheric particulate material. Different studies have shown that low concentrations of metals in particulate material significantly influence on environment and human health. These health effects are more noticeable in the elderly and children (US EPA, 2006). Clean air is a basic health requirement for every human being. However, air pollution across the globe is constantly threatening human health. Presence of heavy metals in environment above maximum concentration level causes toxic effects in environment and on human's health. They enter the human body through food, water, and air. Lead 
and its compounds are toxic; they can enter the human body through food, water, and air (Alushllari and Civici 2014). Also, the presence of lead causes anemia and damage of nervous system (Bastawyet al. 2006). Cadmium is an extremely toxic metal, is commonly found in industrial areas, especially where ore is processing and smelting. Exposure to cadmium can cause a number of harmful health effects due to the ability to induce disturbances in several organs and tissues following either acute or chronic exposure (Marisela, 2006). Chromium is a steely gray and non-oxidation hard metal that is in basic state malleable and lustrous (Costa and Klein, 2006). The purpose of this study is to determine the lead concentration in aerosol samples using different analytical techniques.

\section{Material and Method}

Samples were collected in four stations in the cities of Tirana and Elbasan. There were selected 2 points in Tirana (the terrace of the building of the Ministry of Environment and Mount Dajti building near the former Pioneer Camp) and 2 points in Elbasan (the building of the Public Health Center near the former Metallurgical Combine). Represented aerosol samples analyzed using Atomic Absorption Spectrometer, Analyst 800 Perkin Elmer with Graphite furnace Atomic Absorption Spectrometry (3 analytic methods). Air filter samples are digested according Analytic Method Atomic Absorption Spectrometry. Instrumental conditions for lead are based on the Analytical Methods of Atomic Absorption Spectrometry, from Perkin Elmer. During this study are collected in total 23 aerosol samples and 8 blank filters. For digestion of samples were used three different analytic methods. Lead concentration in samples is measured using three instrumental analytic techniques, Flame Atomic Absorption Spectrometry, Graphite Furnace Atomic Absorption Spectrometry and Fluorescence of X-ray.

Instrumental conditions for lead are based on the Analytical Methods of Atomic Absorption Spectrometry, from Perkin Elmer. Three applications were carried out for the measurement of calibration standards and the measurement of samples. For each element calibration curve equation is linear and passing through point zero. To check the instrumental drift, an aqueous standard solution was analyzed after every three samples.

\section{Results}

We have selected 8 aerosols samples, which are divided in two parts and only one in four parts. We have analyzed a total 18 filter aerosol samples. Aerosol samples are collected in Tirana and Elbasan cities and were analyzed for lead content by using Graphite Furnace Atomic Absorption Spectrometry, Flame Atomic Absorption Spectrometry and X-ray Fluorescence in the Institute of Applied Nuclear Physics, University of Tirana, Albania. 
From results obtained show that the level of lead in aerosol samples was in range: $1.8 \mu \mathrm{g} / \mathrm{L}-2705 \mu \mathrm{g} / \mathrm{L}$. Lead concentration for each method is compared between each other, relative standard deviation was $4.3 \%$.

In Table 1are presented the sampling points, code and amount of aerosol that has passed in paper filter. In table 2 are presented the lead concentration for the analyzed samples according 3 techniques analyses.

Table 1. Sampling points, Tirana and Elbasan Cities

\begin{tabular}{llll}
\hline Nr of Filter & Stations & Vol $(\mathbf{m 3})$ & Code of Samples \\
\hline 118 & Elbasan, Metalurgji & 49.7 & $1 \mathrm{M}$ \\
111 & Elbasan, Metalurgji & 75.2 & $2 \mathrm{M}$ \\
107 & Elbasan, Metalurgji & 4.6 & $3 \mathrm{M}$ \\
110 & Elbasan, Metalurgji & 56.3 & $4 \mathrm{M}$ \\
95 & Elbasan, Qendër & 68 & $8 \mathrm{M}$ \\
105 & Elbasan, Metalurgji & 22.7 & $9 \mathrm{M}$ \\
109 & Elbasan, Metalurgji & 31.9 & $10 \mathrm{M}$ \\
85 & Tiranë, Qendër & 79.5 & $11 \mathrm{M}$ \\
53 & Tiranë, Qendër & 56.6 & $12 \mathrm{M}$ \\
52 & Tiranë, Qendër & 57.3 & $13 \mathrm{M}$ \\
80 & Tiranë, Qendër & 85 & $15 \mathrm{M}$ \\
69 & Tiranë, Qendër & 96.3 & $17 \mathrm{M}$ \\
51 & Mali i Dajtit & 142.7 & $14 \mathrm{M}$ \\
\hline
\end{tabular}

Table 2. Sampling points, Tirana and Elbasan Cities.

\begin{tabular}{lllll}
\hline Nr of Filter & Code of Samples & GF_AAS & F_AAS & XRF \\
\hline 51 & M14 & 2.1 & 0.0 & 1 \\
80 & M15 & 4.0 & 0.0 & 1 \\
52 & M13 & 6.0 & 5.6 & 1 \\
69 & M17 & 6.3 & 0.0 & 42 \\
53 & M12 & 8.8 & 5.7 & 1 \\
85 & M11 & 10.4 & 8.2 & 69 \\
95 & M8 & 20.7 & 11.7 & 1 \\
110 & M4 & 147.1 & 161.5 & 120 \\
105 & M9 & 472.5 & 379.5 & 371 \\
109 & M10 & 610.6 & 465.5 & 640 \\
111 & M2 & 680.4 & 552.0 & 635 \\
118 & M1 & 932.0 & 804.0 & 994 \\
107 & M3 & 2705.3 & 3054.0 & 2811 \\
\hline
\end{tabular}

\subsection{Figures}

There are selected 4 stations to collected aersols samples. In figure 1 is presented map of Albania where are selected 2 cities Tirana and Elbasan 


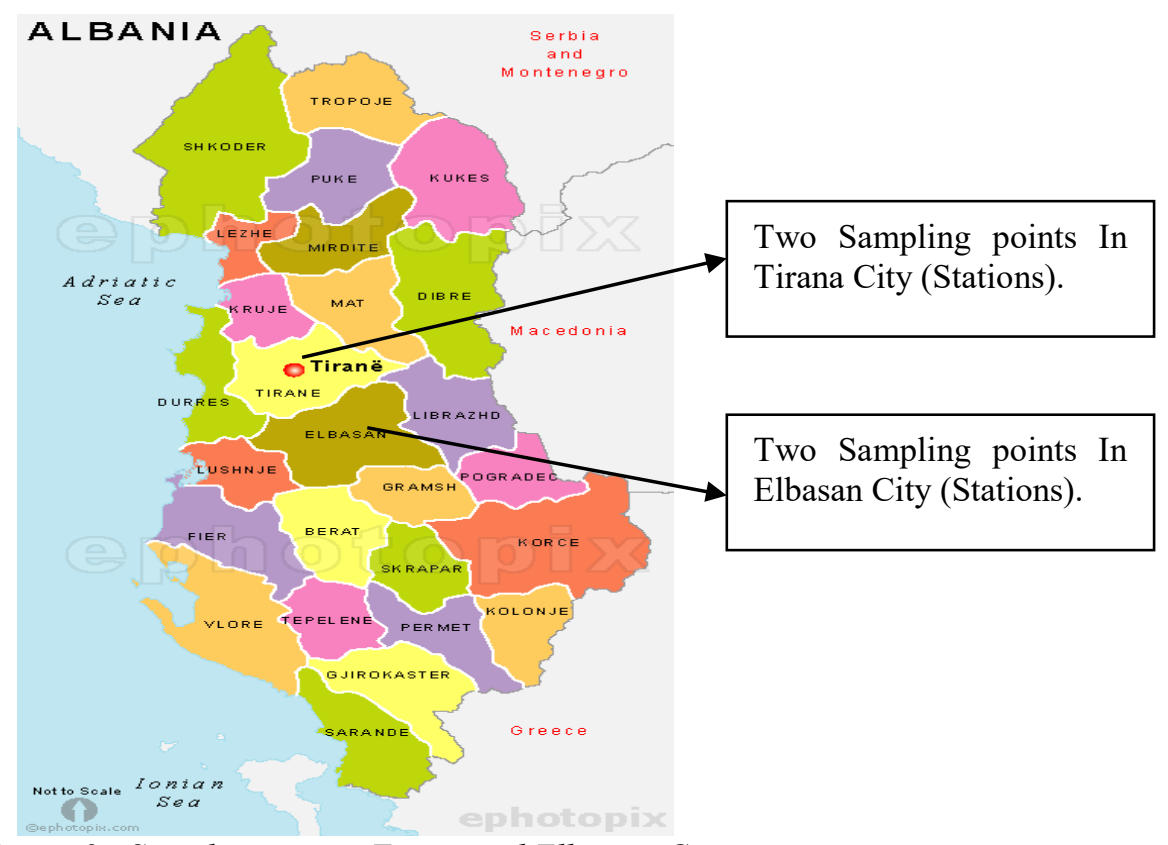

Figure 2: Sampling points, Tirana and Elbasan Cities

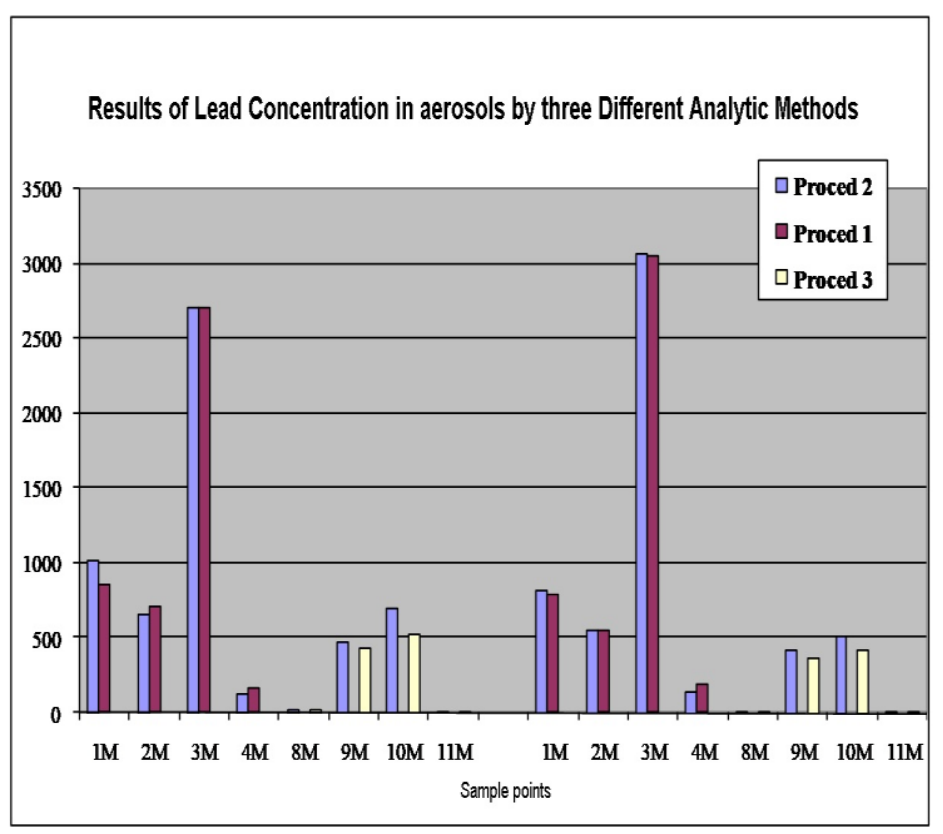

Figure 2: Comparing of Lead concentration in samples by different techniques 
Figure 2: Grafical form of lead concentration by three different methods

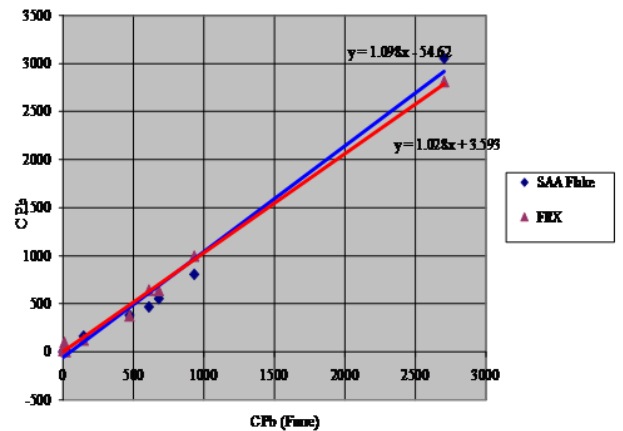

\section{Conclusions}

From the results obtained show that the level of lead in the aerosol samples that are collected in Elbasan is higher than in samples are collected in Tirana. By the use of various techniques in the measurement of lead in aerosols it is noticed that the more information is obtained from the technique of Xray while for the presence of lead in low concentrations, GFAAS technique has the highest accuracy and sensitivity.

Lead concentrations in aerosols samples which are collected in the city of Elbasan were higher than in Tirana, while the most contaminated area was near metallurgical areas. In the descending order of content in aerosols, elements analyzed in selected sampling stations, were ranked: Elbasan metallurgical $>$ Elbasan Center $>$ Tirana Center $>$ Mount of Dajt.

As the main sources of air pollution by metals in Elbasan and Tirana cities were emissions from fuel burning, burning of urban wastes, dust particles transported by wind, construction and inert materials.

In the city of Elbasan, partial work in Metallurgical Combinate significantly contributes to the emission of gases in the air and solid waste in the land. In the descending order of sensitivity of techniques to measure lead concentration were 


\section{References}

1. Alushllari, M., and Civici N, (2014). Analyses of Lead in Water Depend the Weather, near the Ex-Factory Production of Batteries Region, Berat, Albania. Applied Science Reports, 122-125, DOI: 10.15192/PSCP.ASR.2014.1.3.122125.

2. M. Alushllari, Nikolla Civici, Silvana Mico (2014). Analyses of $\mathrm{Cd}, \mathrm{Cr}$ and $\mathrm{Pb}$ Concentration in the Aerosols Using Different Digestion Methods and Different Techniques. "12th International conference of Meteorology, Climatology and Physics of the Atmosphere", 2014; Proceeding book. Pg. 44-48. ISBN: 978-960-524-430-9.

3. A. Seaton, W. MacNee, K. Donaldson and D. Godden, Particulate air pollution and acute health effects Lancet, Vol. 345 (8943), Pages 176 - 178, 1995, doi:10.1016/S0140-6736(95).

4. Bastawy O, Kumar R, Njumbe J, Norell C, Gdal O, Oni S., Svensson L., (2006) . Assessment of Area for Outdoor Swimming Facility at Lindö, Norrkwping Linkoping University.

5. Costa, M., Klein, C. 2006. Toxicity and Carcinogenicity of Chromium Compounds in Humans. In Critical Reviews in Toxicology, vol. 36 (2), 2006. p. 155-163, doi: 10.1080/10408440500534032.

6. Marisela, M., Camilo, R., (2006). Cadmium neurotoxicity, Environmental, Toxicology and Pharmacology, 2007, 23(3):350-8. doi: 10.1016/j.etap.2006.11.009.

7. Perkin-Elmer Corp. 1991. Analytical Methods for Atomic Absorption Spectrophotometry. Recommended conditions for THGA furnaces.

8. U.S. EPA. Air Quality Criteria for Lead (2006) Final Report. U.S. Environmental Protection Agency, Washington, DC, EPA/600/R-05/144aF-bF, 2006.

9. WHO, Air Quality Guidelines for Europe, Copenhagen, Denmark (2000), 2nd Edition, pg 136-154 Cadmium, Chromium and lead. 